\title{
The Effect of PET (Polyethylene Terephthalate) Plastic on Lightweight Concrete
}

\author{
Husnah $^{1}$, Doni R Basri ${ }^{1}$, Puspa Ningrum ${ }^{1}$, Ahmad Zaki2* \\ ${ }^{1}$ Department of Civil Engineering Universitas Abdurrab Pekanbaru, Indonesia \\ ${ }^{2}$ Department of Civil Engineering, Universitas Muhammadiyah Yogyakarta, Indonesia \\ Corresponding author.Email: ahmad.zaki@umy.ac.id
}

\begin{abstract}
Innovation of concrete technology becomes important for conserving energy, according to the building's structural design's weight. Thus, lightweight concrete can be a solution because it has a low density with good quality and optimum strength. One substitute for concrete is plastic, a polymer material with a low density of $92-96 \mathrm{~kg} / \mathrm{m}^{3}$. This study is an experimental study that aims to understand the effect of PET plastic (Polyethylene Terephthalate) usage in the manufacture of lightweight concrete with a design quality of $250 \mathrm{~kg} / \mathrm{cm}^{2}$. The experimental work begins with a test of the material's properties and then prepares a concrete mixture formula. The result shows that around $40 \%$ PET mixture percentage with the concrete compressive strength of 250 $\mathrm{kg} / \mathrm{cm}^{2}$ (14 days old) and $205 \mathrm{~kg} / \mathrm{cm}^{2}$ (28 days). In contrast, the weight that meets the SNI standard of lightweight concrete is $100 \%$ PET Variation.
\end{abstract}

Keywords—experimental study, lightweight concrete, polyethylene terephthalate

\section{INTRODUCTION}

Lightweight concrete is concrete with a density that is lighter than normal concrete. Lightweight concrete is good to be used for tall buildings to reduce the load of the building. Unlike the normal concrete, the weight of lightweight concrete can be arranged as needed. According to SNI 03-2847-2002 [1], lightweight concrete contains light aggregate and has a unit weight of no more than $1900 \mathrm{~kg} / \mathrm{m}^{3}$. Lightweight concrete is obtained by adding air pores to the concrete mixture. Based on Dobrowolski [2], lightweight concrete is divided into three categories, i.e. (a) concrete with low compressive strength (Low-Density Concrete) with a density of $240-800 \mathrm{~kg} / \mathrm{m}^{3}$ and compressive strength of 0,35-6,9 $\mathrm{MPa}$, (b) moderate-strength lightweight concrete with the density of $800-1440 \mathrm{~kg} / \mathrm{m}^{3}$ and compressive strength of 6,9-17,3 $\mathrm{MPa}$, and (c) structural lightweight concrete with the density of $1440-1900 \mathrm{~kg} / \mathrm{m}^{3}$ and compressive strength of more than $17,3 \mathrm{MPa}[3]$.

The material used to produce lightweight concrete and the composition are the same as the material used to produce normal concrete, but in the manufacturing of lightweight concrete, the coarse aggregate is changed with other material, which has lighter density, which is lightweight aggregate [4][5][3]. In accordance to SNI 03-3449- 2002[1], lightweight aggregate is the aggregate with filling weight for the dry oven of a maximum of $1100 \mathrm{~kg} / \mathrm{m}^{3}$.

In this study, the coarse aggregate was partially replaced by PET plastic [6]. PET plastic was selected because it has a lighter density than the rough aggregate. In many studies,
PET plastic is processed to become aggregate by cutting, cleaning, melting, cooling, and crushing processes before being used [7]. In lightweight concrete, PET plastic is used as the replacement of coarse aggregate in concrete material [7][8][9]. Frigione [7] attempted to replace the $5 \%$ by weight of natural sand with an equivalent weight of PET aggregates derived from unwashed waste PET (WPET) bottles in concrete. Aswatama et al. [8] studied the effect of $2.5 \% ; 5 \% ; 7.5 \%$; and $10 \%$ PET waste on self-compacting concrete (SCC). Akçaözoğlu et al. [9] investigated the utilization of shredded waste Poly-ethylene Terephthalate (PET) bottle granules as a lightweight aggregate in mortar. Unlike previous studies mentioned above, this study focuses on using local aggregates with PET as a partial substitute of coarse aggregate that has not been previously reported. The compressive strength of concrete obtained varies by a different percentage of substitute aggregates is obtained.

\section{MATERIAL AND METHOD}

Portland Composite Cement (PCC) has also been used as the main material in cement mixture and PET as a partial substitute of coarse aggregate to manufacture lightweight concrete. PET plastic has high mechanical strength, is transparent, non-toxic, and has no negligible effect on the taste and the permeability of carbon dioxide. PET plastic has excellent tensile and impact strength and its chemical resistance, clarity, processability, colorability, and thermal stability. The materials used are local materials. The properties of local materials in this research have fine modulus of the fine aggregate of about 2.8 , and then have 
2.68 specific gravity and absorption percentage of $3.11 \%$. For coarse aggregate, it has a specific gravity of 2.77 and an absorption percentage of $3.61 \%$. The Indonesian Standard guides this research used, SNI 03- 6468-2000 for a mix design method of normal concrete. The composition and the mix design with the addition of PET plastic also followed the normal concrete method. The addition of PET plastic was carried out according to the variation in the PET mixture percentage. Percentage variation of PET plastic were $0 \%, 40 \%, 50 \%, 70 \%$ and $100 \%$. In this research, the experimental study of the testing 26 specimens was cubeshaped with the quality of the concrete design was 250 $\mathrm{kg} / \mathrm{cm}^{2}$, and each variation of PET has three samples. Testing begins with testing the material's properties first so that the concrete mixture's composition is $1 \mathrm{~m}^{3}$. The composition of the mixture is shown in Table I.

Table I. Mixtures Composition for $1 \mathrm{M}^{3}$ of Concrete

\begin{tabular}{|l|c|c|c|c|c|}
\hline \multicolumn{1}{|c|}{ Material } & $\begin{array}{c}\text { Normal } \\
\text { Concrete } \\
(\mathbf{k g})\end{array}$ & $\begin{array}{c}\mathbf{4 0 \%} \\
\text { PET }\end{array}$ & $\begin{array}{c}\mathbf{5 0 \%} \\
\text { PET }\end{array}$ & $\begin{array}{c}\mathbf{7 0 \%} \\
\text { PET }\end{array}$ & $\begin{array}{c}\mathbf{1 0 0 \%} \\
\text { PET }\end{array}$ \\
\hline Water & 229.48 & 229.48 & 229.48 & 229.48 & 229.48 \\
\hline Cement & 400.00 & 400.00 & 400.00 & 400.00 & 400.00 \\
\hline Fine Aggregate & 738.19 & 738.19 & 738.19 & 738.19 & 738.19 \\
\hline $\begin{array}{l}\text { Coarse } \\
\text { Aggregate }\end{array}$ & 874.08 & 524.45 & 437.04 & 262.22 & - \\
\hline PET & - & 349.63 & 437.04 & 611.86 & 874.08 \\
\hline
\end{tabular}

The composition of PET's use in the study [7]. The amount of waste plastic bottles or Polyethylene Terephthalate (PET) added to the concrete was $0.40 \%$; $0.50 \% ; 0.70 \% ; 100 \%$. It is afraid to see the effect of chopped plastic bottles used on lightweight concrete. As a reference of mix design, concrete is created without PET plastic $(0 \%$ PET). The addition of PET as a partial substitute of the coarse aggregate in 1 cube mold concrete mixture. The proportions of the material are presented in Table II.

Table II. Mixtures Composition with the Addition of Pet Plastic for 1 Cube Mold

\begin{tabular}{|c|c|c|c|c|c|c|}
\hline \multirow{2}{*}{$\begin{array}{c}\text { Percentag } \\
\text { e variation } \\
\text { of PET }\end{array}$} & \multirow{2}{*}{$\begin{array}{c}\text { Volume } \\
\left(\mathrm{m}^{3}\right)\end{array}$} & \multicolumn{5}{|c|}{ Material } \\
\hline & & $\begin{array}{c}\text { Cement } \\
\text { (kg) }\end{array}$ & $\begin{array}{c}\text { Water } \\
\text { (kg) }\end{array}$ & $\begin{array}{c}\text { Sand } \\
(\mathrm{kg})\end{array}$ & $\begin{array}{c}\text { Crushed } \\
\text { stone } \\
(\mathbf{K g}) \\
\end{array}$ & $\begin{array}{l}\text { PET } \\
(\mathrm{Kg})\end{array}$ \\
\hline $0 \%$ & 0.0034 & 1.63 & 0.94 & 3.01 & 3.56 & - \\
\hline $40 \%$ & 0.0034 & 1.63 & 0.94 & 3.01 & 2.14 & 1.42 \\
\hline $50 \%$ & 0.0034 & 1.63 & 0.94 & 3.01 & 1.78 & 1.78 \\
\hline $70 \%$ & 0.0034 & 1.63 & 0.94 & 3.01 & 1.07 & 2.49 \\
\hline $100 \%$ & 0.0034 & 1.63 & 0.94 & 3.01 & - & 3.56 \\
\hline
\end{tabular}

\section{RESULTS AND DISCUSSION}

Table III indicates that the highest compressive strength test at the 14 days was obtained when the PET of the specimen was $40 \%$, namely the compressive strength average of concrete is $250 \mathrm{~kg} / \mathrm{cm}^{2}$. The compressive strength of concrete decreases along with PET's addition as a substitute for coarse aggregate, but it can still be used in non-structural applications.

Table IV shows that the compressive strength test at 28 days did not change significantly. The compressive strength obtained in the 28-day test with an optimum compressive strength of $205 \mathrm{~kg} / \mathrm{cm}^{2}$ on $40 \%$ of PET variations and a decrease in the compressive strength of the concrete and PET's addition as a substitute for coarse aggregate.

Table III. Compressive Strength Test on 14 Days

\begin{tabular}{|c|c|c|c|c|c|c|}
\hline Variation & $\begin{array}{c}\text { Weight } \\
\text { (Kg) }\end{array}$ & $\begin{array}{c}\text { Sectional area } \\
\left(\mathrm{cm}^{2}\right)\end{array}$ & $\begin{array}{c}\text { Compressive force } \\
(\mathbf{k N})\end{array}$ & $\begin{array}{l}\text { Correction } \\
\text { factor }\end{array}$ & $\begin{array}{c}\text { Compressive Strength } \\
\left(\mathbf{k g} / \mathrm{cm}^{2}\right)\end{array}$ & $\begin{array}{c}\text { Compressive } \\
\text { Strength average }\left(\mathrm{kg} / \mathrm{cm}^{2}\right)\end{array}$ \\
\hline $0 \%$ & 7.90 & 225 & 525 & 0.88 & 270 & 270 \\
\hline $40 \%$ & 7.46 & 225 & 480 & 0.88 & 247 & \multirow{3}{*}{250} \\
\hline $40 \%$ & 7.43 & 225 & 520 & 0.88 & 268 & \\
\hline $40 \%$ & 7.30 & 225 & 455 & 0.88 & 234 & \\
\hline $50 \%$ & 6.90 & 225 & 395 & 0.88 & 203 & \multirow{3}{*}{205} \\
\hline $50 \%$ & 6.94 & 225 & 425 & 0.88 & 219 & \\
\hline $50 \%$ & 6.96 & 225 & 375 & 0.88 & 193 & \\
\hline $70 \%$ & 6.62 & 225 & 330 & 0.88 & 170 & \multirow{3}{*}{179} \\
\hline $70 \%$ & 6.70 & 225 & 340 & 0.88 & 175 & \\
\hline $70 \%$ & 6.56 & 225 & 375 & 0.88 & 193 & \\
\hline $100 \%$ & 5.90 & 225 & 300 & 0.88 & 155 & \multirow{3}{*}{154} \\
\hline $100 \%$ & 5.81 & 225 & 300 & 0.88 & 155 & \\
\hline $100 \%$ & 5.82 & 225 & 295 & 0.88 & 152 & \\
\hline
\end{tabular}

Table IV. Compressive Strength Test on 28 Days

\begin{tabular}{|c|c|c|c|c|c|c|}
\hline Variation & $\begin{array}{c}\text { Weight } \\
\text { (Kg) }\end{array}$ & $\begin{array}{c}\text { Sectional area } \\
\left(\mathrm{cm}^{2}\right)\end{array}$ & $\begin{array}{c}\text { Compressive force } \\
(\mathrm{kN})\end{array}$ & $\begin{array}{r}\text { Correctio } \\
\text { n factor }\end{array}$ & $\begin{array}{c}\text { Compressive Strength } \\
\left(\mathrm{kg} / \mathrm{cm}^{2}\right)\end{array}$ & $\begin{array}{c}\text { Compressive } \\
\text { Strength average }\left(\mathrm{kg} / \mathrm{cm}^{2}\right)\end{array}$ \\
\hline $0 \%$ & 7.90 & 225 & 585 & 1.00 & 265 & 265 \\
\hline $40 \%$ & 7.46 & 225 & 435 & 1.00 & 197 & \multirow{3}{*}{205} \\
\hline $40 \%$ & 7.43 & 225 & 470 & 1.00 & 213 & \\
\hline $40 \%$ & 7.30 & 225 & 450 & 1.00 & 204 & \\
\hline $50 \%$ & 6.90 & 225 & 475 & 1.00 & 215 & \multirow{3}{*}{214} \\
\hline $50 \%$ & 6.94 & 225 & 475 & 1.00 & 215 & \\
\hline $50 \%$ & 6.96 & 225 & 465 & 1.00 & 211 & \\
\hline $70 \%$ & 6.62 & 225 & 435 & 1.00 & 197 & \multirow{3}{*}{193} \\
\hline $70 \%$ & 6.70 & 225 & 435 & 1.00 & 197 & \\
\hline $70 \%$ & 6.56 & 225 & 405 & 1.00 & 184 & \\
\hline $100 \%$ & 5.90 & 225 & 325 & 1.00 & 147 & \multirow{3}{*}{143} \\
\hline $100 \%$ & 5.81 & 225 & 310 & 1.00 & 141 & \\
\hline $100 \%$ & 5.82 & 225 & 310 & 1.00 & 141 & \\
\hline
\end{tabular}


Fig. 1 presented that the highest compressive strength was obtained when the mixture contained $40 \%$ of PET and decreases in the concrete's compressive strength and the addition of using PET as a substitute for aggregate.

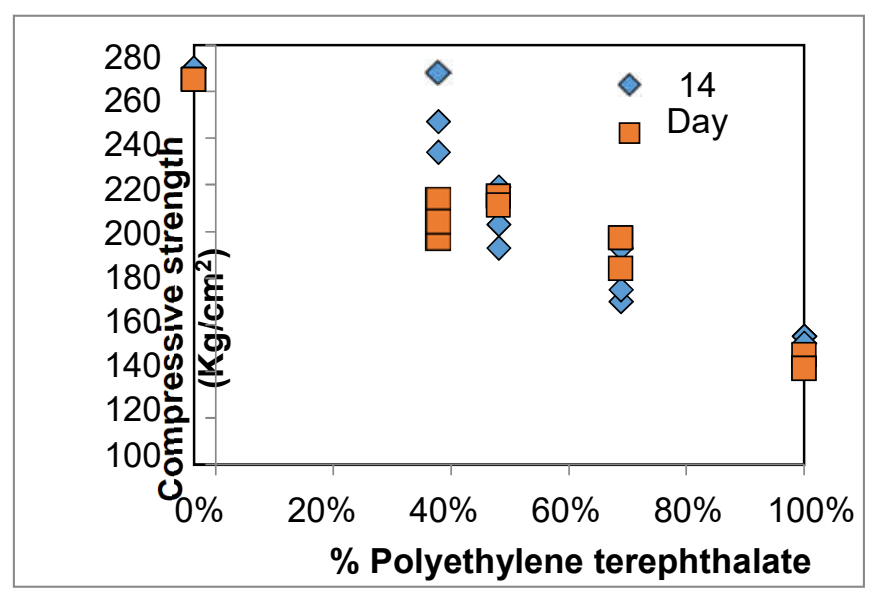

Fig 1. The compressive strength of concrete with variation of addition PET on 14 and 28 days of age

Based on SNI 03-2847-2002 [1], structural lightweight concrete has lightweight aggregates with a maximum weight of $1900 \mathrm{Kg} / \mathrm{m}^{3}$. So that in terms of weight in the cube test object is:

$$
\text { Weight of } 1 \mathrm{~m}^{3}=1900 \mathrm{Kg} / \mathrm{m}^{3} ; \text { Volume }=0.00337 \mathrm{~m}^{3}
$$

Weight of specimen $=$ Weight of $1 \mathrm{~m}^{3} \times$ Volume $=1900$ $\mathrm{Kg} / \mathrm{m}^{3} \times 0.00337 \mathrm{~m}^{3}=6.4 \mathrm{Kg}$.

The weight average of the cube specimen on 14 days can be seen in Table V. Data on the results of the average weight of cube specimens at the age of 28 days, which are included in the classification of lightweight concrete, can be seen in Table VI.

The use of PET plastic is included in the lightweight concrete category, which is the average weight of the cube specimens at the age of 14 days with the Percentage variation of PET plastic used were $0 \%, 40 \%, 50 \%, 70 \%$, and $100 \%$ respectively, namely $7.90 \mathrm{~kg}, 7.40 \mathrm{~kg}, 6.93 \mathrm{~kg}, 6.63 \mathrm{~kg}$, and $5.84 \mathrm{~kg}$. Meanwhile, at the age of 28 days, respectively, namely $7.75 \mathrm{~kg}, 6.97 \mathrm{~kg}, 6.77 \mathrm{~kg}, 6.41 \mathrm{~kg}$, and $5.84 \mathrm{~kg}$. The classification of lightweight concrete, according to SNI 03$3449-2002$ in $1 \mathrm{~m}^{3}$ with a weight of $1900 \mathrm{Kg} / \mathrm{m}^{3}$. The cube specimen classified as lightweight concrete has a maximum weight of $6.4 \mathrm{Kg}$ so that the weight of the cube specimen is classified as lightweight concrete at the age of 14 days and at the age of 28 days with the addition of $100 \%$ PET is about $5.84 \mathrm{~kg}$.
Table V. Weight Average of Cube Specimen on 14 Days of Age

\begin{tabular}{|c|c|c|c|}
\hline Variation & Weight (kg) & Weight average $(\mathrm{Kg})$ & Weight SNI (Kg) \\
\hline $0 \%$ & 7.90 & 7.90 & 6.4 \\
\hline $40 \%$ & 7.46 & \multirow{3}{*}{7.40} & \multirow{3}{*}{6.4} \\
\hline $40 \%$ & 7.43 & & \\
\hline $40 \%$ & 7.3 & & \\
\hline $50 \%$ & 6.90 & \multirow{3}{*}{6.93} & \multirow{3}{*}{6.4} \\
\hline $50 \%$ & 6.94 & & \\
\hline $50 \%$ & 6.96 & & \\
\hline $70 \%$ & 6.62 & \multirow{3}{*}{6.63} & \multirow{3}{*}{6.4} \\
\hline $70 \%$ & 6.70 & & \\
\hline $70 \%$ & 6.56 & & \\
\hline $100 \%$ & 5.90 & \multirow{3}{*}{5.84} & \multirow{3}{*}{6.4} \\
\hline $100 \%$ & 5.81 & & \\
\hline $100 \%$ & 5.82 & & \\
\hline
\end{tabular}

TABLE VI. WEIGHT AVERAGE OF CUBE SPECIMEN ON 28 DAYS OF AGE

\begin{tabular}{|c|c|c|c|}
\hline Variation & Weight (kg) & $\begin{array}{c}\text { Weight average } \\
(\mathrm{Kg})\end{array}$ & $\begin{array}{c}\text { Weight SNI } \\
(\mathrm{Kg})\end{array}$ \\
\hline $0 \%$ & 7.75 & 7.75 & 6.4 \\
\hline $40 \%$ & 6.93 & \multirow{3}{*}{6.97} & \multirow{3}{*}{6.4} \\
\hline $40 \%$ & 6.93 & & \\
\hline $40 \%$ & 7.06 & & \\
\hline $50 \%$ & 6.74 & \multirow{3}{*}{6.77} & \multirow{3}{*}{6.4} \\
\hline $50 \%$ & 6.75 & & \\
\hline $50 \%$ & 6.83 & & \\
\hline $70 \%$ & 6.43 & \multirow{3}{*}{6.41} & \multirow{3}{*}{6.4} \\
\hline $70 \%$ & 6.43 & & \\
\hline $70 \%$ & 6.39 & & \\
\hline $100 \%$ & 5.81 & \multirow{3}{*}{5.84} & \multirow{3}{*}{6.4} \\
\hline $100 \%$ & 5.8 & & \\
\hline $100 \%$ & 5.82 & & \\
\hline
\end{tabular}

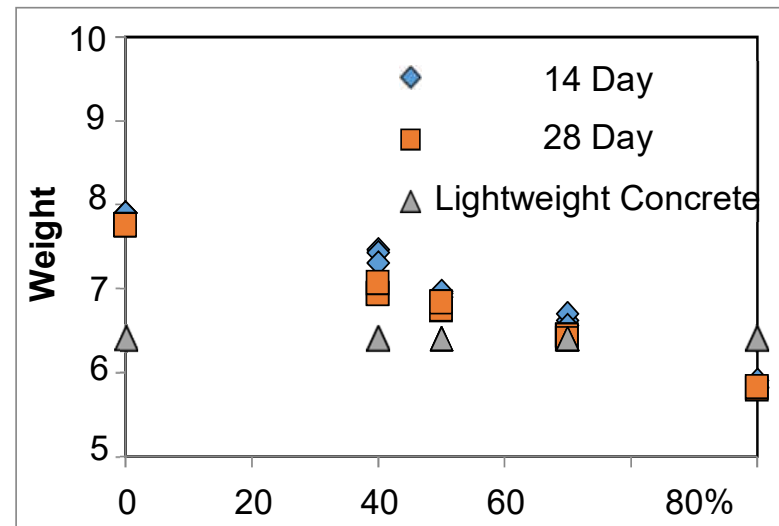

Fig 2. Weight of the spedinglyethyderet on 14 and 28 days of age, and SNI for lightweight concrete

\section{CONCLUSION}

The weight of the concrete decreases with the use of PET plastic (Polyethylene Terephthalate). Weight average of cube specimen on 28 days of age using percentage variation of PET $0 \%, 40 \%, 50 \%, 70 \%$, and $100 \%$ respectively, namely $7.75 \mathrm{~kg}, 6.97 \mathrm{~kg}, 6.77 \mathrm{~kg}, 6.41 \mathrm{~kg}$, and $5.84 \mathrm{Kg}$. The 
compressive strength of the concrete decreases with the greater use ofPET plastic. The highest average compressive strength is obtained by cube, specimens used $40 \%$ plastic bottle waste (PET), namely $250 \mathrm{Kg} / \mathrm{cm}^{2}$. The lightweight concrete category with the maximum weight of the cube specimen is $6.24 \mathrm{~kg}$. The cube specimen is classified as light concrete at 14 days and 28 days with $100 \%$ PET. In the cube specimen, the age of 14 days is $5.84 \mathrm{~kg}$ and at the age of 28 days is $5.84 \mathrm{~kg}$

\section{REFERENCES}

[1] B. S. Nasional, "Tata CaraCampuran Beton Ringan Dengan Agregat Ringan SNI 03-3449-2002," Badan Standar Nasional. Jakarta, 2002.

[2] J. A. Dobrowolski, Concrete construction handbook. McGraw- Hill, 1998.

[3] A. M. Hameed and B. A. F. Ahmed, "Employment the plastic waste to produce the light

[4] weight concrete," Energy Procedia, vol. 157, pp. 30 38, 2019

[5] D. G. Alfiandi, "Pengaruh Penggunaan Limbah Plastik PET Sebagai Agregat Kasar Pada Beton Ringan Struktural," 2016.
[6] I. M. Nikbin, S. Rahimi, H. Allahyari, and F. Fallah, "Feasibility study of waste Poly Ethylene Terephthalate (PET) particles as aggregate replacement for acid erosion of sustainable structural normal and lightweight concrete," J. Clean. Prod., vol. 126, pp. 108117, 2016.

[7] Y.-W. Choi, D.-J. Moon, J.-S. Chung, and S.-K. Cho, "Effects of waste PET bottles aggregate on the properties of concrete," Cem. Concr. Res., vol. 35, no. 4, pp. 776-781, 2005.

[8] M. Frigione, "Recycling of PET bottles as fine aggregate in concrete," Waste Manag., vol. 30, no. 6, pp. 1101-1106, 2010.

[9] K. Aswatama W, H. Suyoso, N. Meyfa U, and P. Tedy, "The effect of adding PET (Polyethylen Terephthalate) plastic waste on SCC (selfcompacting concrete) to fresh concrete behavior and mechanical characteristics," JPhCS, vol. 953, no. 1, p. 12023, 2018.

[10] S. Akçaözoğlu, C. D. Atiş, and K. Akçaözoğlu, "An investigation on the use of shredded waste PET bottles as aggregate in lightweight concrete," Waste Manag., vol. 30, no. 2, pp. 285290, 2010. 